\author{
Clothes Make the Irish: Irish Dressing and the Question of Identity \\ Christian Huck \\ published in: Irish Studies Review 11:3 (2003), 273-284.
}

Irish Studies Review, Vol. 11, No. 3, 2003

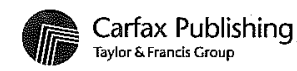

\title{
Clothes Make the Irish: Irish Dressing and the Question of Identity
}

CHRISTIAN HUCK, Hamburg University

When the Ladies' Committee of the Irish Clothing Committee (of the Society of Friends) launched An Appeal for Clothing the Naked and Destitute Irish in 1847 they probably did what's worst: they meant well. By trying to help the inhabitants of a famine-ridden Ireland, 'the poor perishing, half-clad, and in some cases, naked Irish', they confirmed a stereotype that had slowly evolved during the foregoing centuries: the Irish stand closer to the naked and uncultivated beast than to a well-dressed and civilised human (i.e. English). To help cultivate the Irish they have to be helped into proper clothing, even if these are only second-hand English garments. However, soon after half the nation had been dressed in 'stout flannel jackets' and 'flannel petticoats' [1] that these well-meaning English ladies had collected, this logic was to be turned around in the spirit of the Irish Renaissance. In 1886 a pamphlet was published on How to Dress in Irish Materials [2]. The Irish, wrongly civilised (Anglicised), were to be dressed in an Irish dress to be Irish (again). But why have the Irish to be dressed Irish to be Irish? And what is an Irish dress, and where had it gone?

When I first presented some of the following observations at the New Voices in Irish Criticism conference in Dublin, the initial reaction was sceptical: What of essence could be said about the most superficial world of clothes and fashion? While feminist criticism has always acknowledged the engendering work of dress, the role of clothes in other identity-formations has been thoroughly overlooked, or rigorously criticised as a hegemonic tool of oppression. However, this essay tries to ponder the question of (Irish) identity by looking at descriptions of Irish dress. Taking the formative powers of textiles into consideration, I will analyse images of clothing in historical writings on Ireland and in Irish writing itself. After a necessarily brief overview of the role of clothes in several (in)famous depictions of Ireland I will take a closer look at the idea of an Irish dress in Douglas Hyde's 'The Necessity for De-Anglicising Ireland'. Finally, I will briefly examine the role of textiles in twentieth-century discussions of Irish identity. The aim of this essay is to present clothes not as a surface that hides a hidden (true) meaning but as a texture that makes sense, a surface that produces depth. As this has not been examined much before, the following observation can only present a first overview of the various uses of dress in writings on and from Ireland. (To restrict myself, I will not comment on the highly engendered status of much of this writing, which will be easily discernible for any reader.)

So, how has the Irish dress been perceived in the past? Medieval chroniclers of Irish life, very much like modern critics, seemed not to believe that it is worth much consideration at all. Giraldi Cambrensis goes into great detail when presenting the Irish flora and fauna, but is less meticulous when it comes to Ireland's human inhabitants. He believes Irish customs and manners, apart from their music, to be of such low

ISSN 0967-0882 print/ISSN 1469-9303 online/03/030273-12 (c) 2003 Taylor \& Francis Ltd DOI: $10.1080 / 09670880310001629811$ 


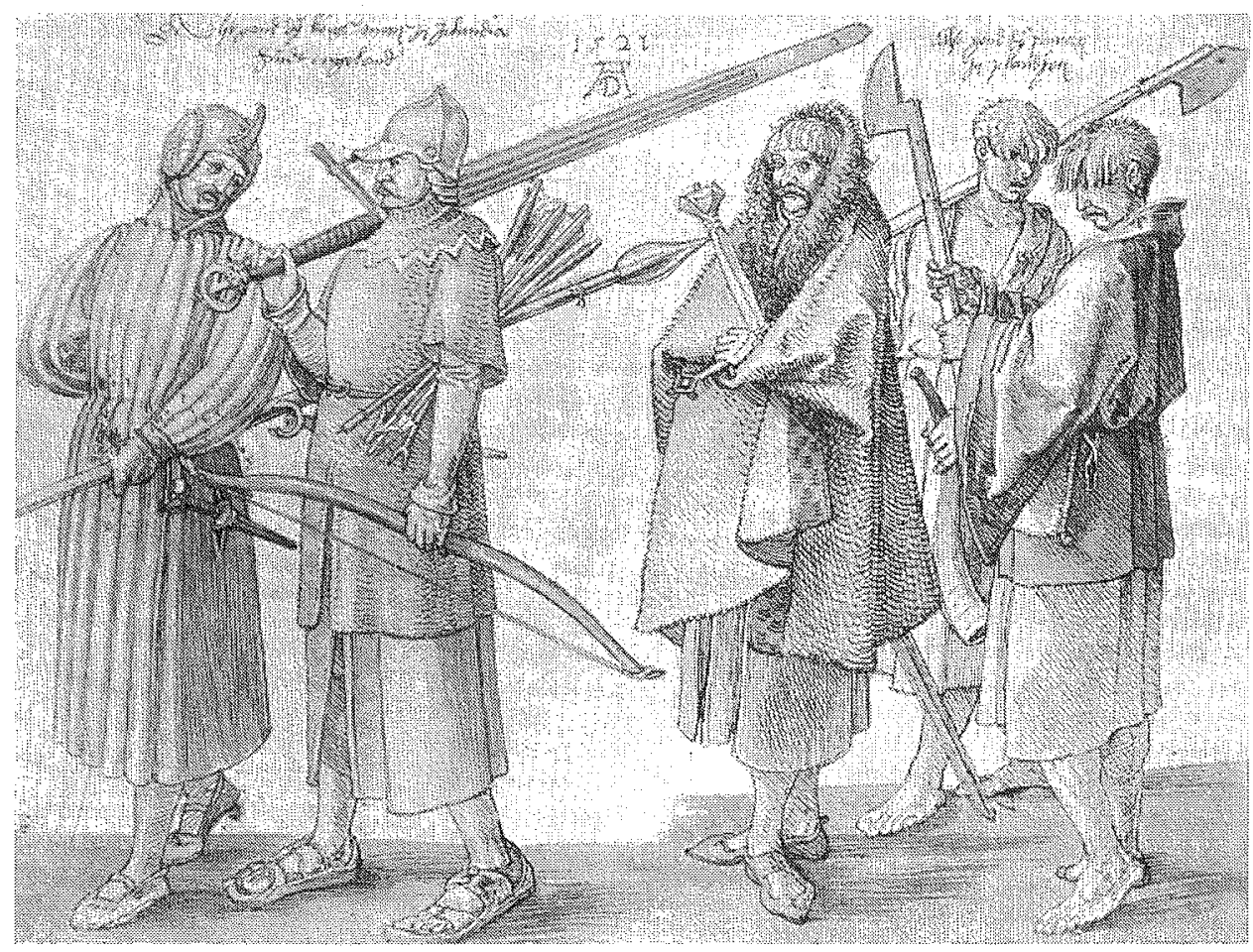

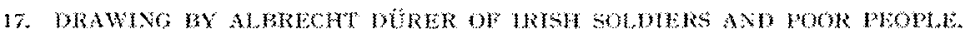

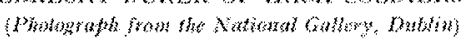

Fig. 1. H. F. McClintock: Old Ireland E' Highland Dress (Dundalgan Press, 1950).

development that they are merely a sign of barbarism: 'They are a wild and inhospitable people. They live on beasts only, and live like beasts. They have not progressed at all from the primitive habits of pastoral living.' Their dress is only one further proof for their backwardness: 'They use very little wool in their dress and that itself nearly always black-because the sheep of that country are black-and made up in a barbarous fashion. For they wear little hoods, close-fitting and stretched across the shoulders [...]. Under these they wear mantles instead of cloaks' [3]. It becomes evident that the combined representations of the fertility of the Irish land and the cultural and religious backwardness of the native inhabitants are mere steps towards justifying a (future) English rule over Ireland. According to this reasoning, the English have to cultivate the Irish and the Irish land because the uncultivated Irish are not even able to cultivate themselves-as their dress shows. The Irish way of living was not considered to be a culture of its own, but an uncivilised existence that had yet to be cultivated, and properly dressed.

Nearly 200 years later, such an apparently justified English rule was still not fully accomplished. Edmund Spenser's View of the Present State of Ireland suggests that this is mainly due to the 'difference in manners and customs' [4]. He presents in much more detail the peculiar way of living across the Irish Sea. Concerning the apparel, he describes the Irish custom of 'wearing mantles and long glibs, which is a thick curled bush of hair hanging down over their eyes, and monstrously disguising them' [5]. Above all, the mantle is of particular concern to Spenser, because he thinks it 'a fit house 
for an outlaw, a meet bed for a rebel, and an apt cloak for a thief [6]. He goes on to explain these uses in great detail:

First the outlaw being for his many crimes and villanies banished from the towns and houses of honest man [...] maketh his mantle his house, [...]. Likewise for a rebel it is serviceable: for in his war that he maketh (if at least it deserves the name of war) when he still flyeth from his foe and lurketh in the thick woods and straight passages (waiting for advantages), it is his bed, yea and almost all his household stuff. [...] Lastly, for a thief it is so handsome, as if it may seem it was first invented for him, for under it he can cleanly convey any fit pillage that cometh handsomely in his way [...]. [7]

The Irish dress is still not considered to be an expression of a particular culture; but rather than just being an offence to the (heavenly) command to cultivate man and his environment, it is now seen as a device to evade the law. Spenser uses large parts of his text to explain failures of the ancient Irish (Brehon) law and its inferiority to a modern, universal (English) law. Since Ireland was declared a kingdom in 1541, all inhabitants of the island were subjected to the new law, and to be a subject they have to be identifiable, which is impossible as long as they are 'monstrously disguised'. One of the central pillars of this modern law was (and is) the state monopoly on the use of force. The Irish mantle endangers this monopoly because it allows the Irish to 'go privily, armed without suspicion of any, [to] carry his headpiece, his skene or pistle' [8]. From now on, someone who conceals himself or herself from the eyes of the law is always under the suspicion of evading it. No wonder Spenser complains that the 'law enacted against wearing of Irish apparel' is not 'observed by any or executed by them that have the charge' [9]. Such a law was passed in Kilkenny at the end of the sixteenth century: 'A bye law in the corporation of Irishtown: that no inhabitant dwelling within the mitre land, being a free-man, or woman, wear no apparel but after the English fashion' [10]. Following a similar reasoning, John Davies's Discovery of the True Causes why Ireland was never Entirely Subdued proclaims that the Irish did not rise 'from Barbarisme to Civilitie' [11] under earlier sovereigns because these rulers 'did not abolish the Irish customs' [12]. Again, the central task is to make the Irish accept the modern law: 'the execution of the Law doth make the Irish grow civil, and become English' [13]. To impose the rule of the modern law onto the Irish, the English have to cause 'them to cut off their Glibs and long Haire, to convert their Mantles into Cloaks' [14]. Again, the question of the right garment is not one of cultural identity but one of subjection to the law.

It is obvious from these few citations that even though Spenser and Davies use the terms English and Irish, they do not write as cultural anthropologists who record different ways of living (and clothing) but simply distinguish between an old, barbaric, unlawful way of life and a new, civil, law-abiding way. Therefore, when it comes to the peculiar Irish custom of wearing mantles, Spenser has to concede that 'anciently it was common to most [nations]' [15]. Central to this Renaissance reasoning is the idea that one can cultivate anyone by bringing him or her culture, that everyone can be part of the new world. Natural, innate, or even racial requirements have not to be met to become English, that is, cultivated. On the contrary, Spenser emphasises the fundamental humanistic premise that every human is the same and that it was a singular providence of God [...] to mingle nations [...] to make as it were one kindred and blood of all people' [16]. The difference between the English and the Irish is therefore only a matter of development, of proper manners and proper clothing, not one of essence or 


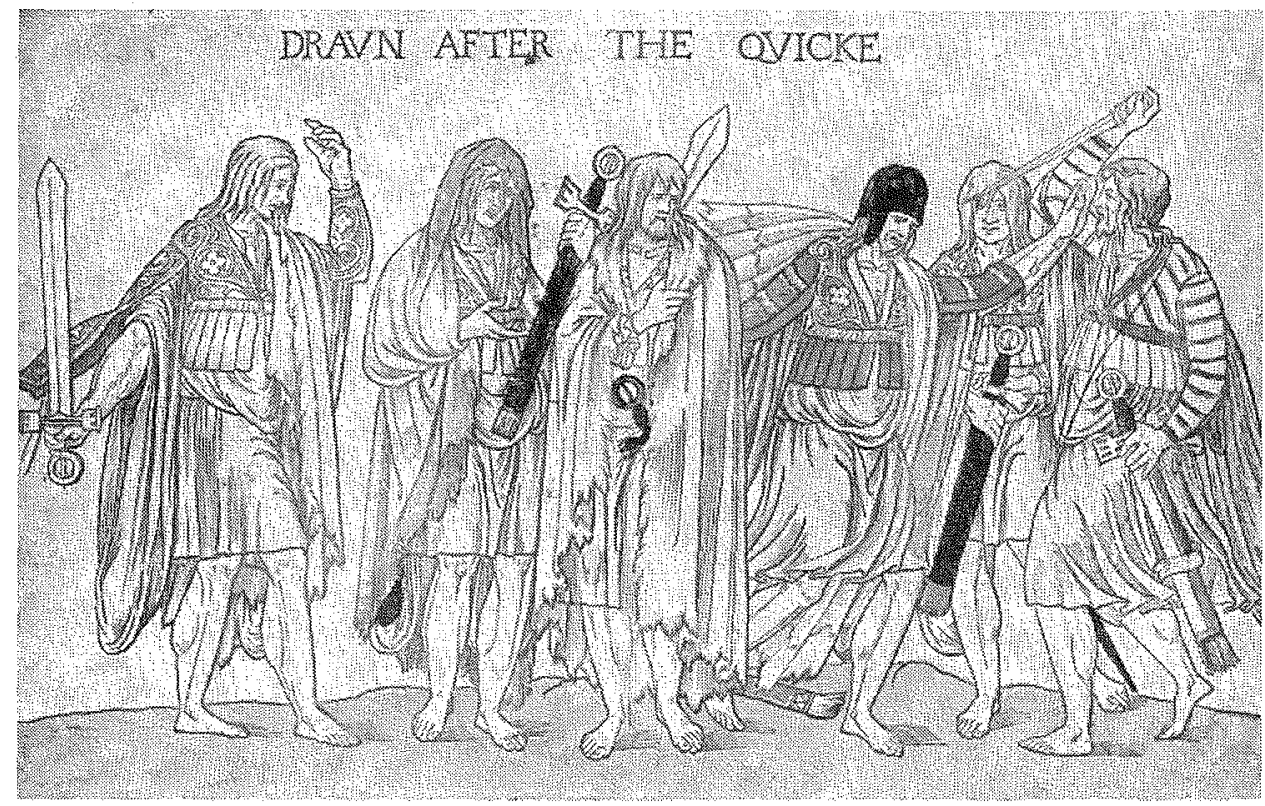

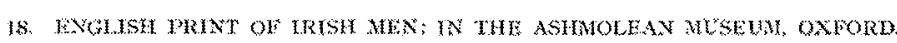

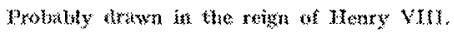

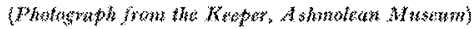

FIG. 2. H. F. McClintock: Old Ireland E Highland Dress (Dundalgan Press, 1950).

blood. And to dress the Irish properly is to cultivate them, because 'there is not a little in the garment to the fashioning of the mind' [17]. For the Renaissance thinker, the inside can be changed by changing the outside [18].

Whereas the equality of mankind remained central during the Enlightenment era of the seventeenth and early eighteenth century, the Romantic countermovement famously emphasised the particularity of different peoples and made the binary opposition of barbarism and civility crumble in favour of an acknowledgement of the multiplicity of cultures. This development was not least brought forward by an exponential rise in travel to new and unknown territories and the subsequent discovery of countless other ways of living, and dressing [19]. The realisation that one's own way of living is not simply the inevitable consequence of practical considerations can be seen as the result of coming into contact with other groups of people who live (and dress) visibly differently. The observation that other people wear other garments to keep themselves warm, make themselves desirable or represent their social status reveals an element of contingency in the choice of dress; or rather, it discloses the fact that there is a choice involved at all. It becomes manifest that clothes-but also cooking, architecture, music, armoury, funeral rites, etc.- -are not determined solely by one's nature but form a sphere of their own, that is, a culture [20]. This gives rise to the possibility of distinguishing between different cultures. Culture in this sense describes a certain way of living of a particular group [21]. This particularity of a group is what is commonly referred to as its identity. Only now, in the late eighteenth century, do we find the idea that a particular group of people forms (and has) a particular culture that is supposed to be the basis of a particular nation [22].

Unfortunately, by the time such an ethnographic view was developed, what had been 


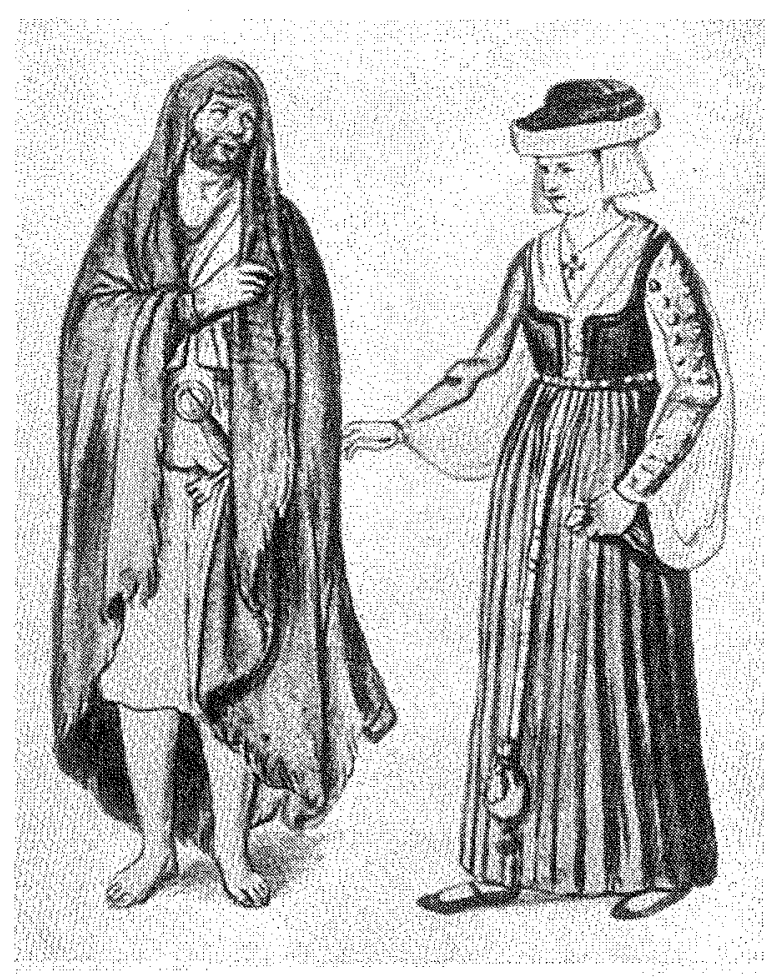

21. WhTK

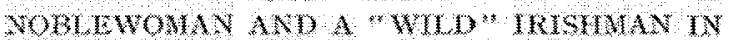

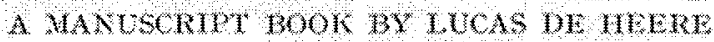
in the Library of Ghent Unversity, Bedium.

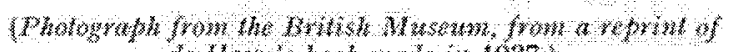

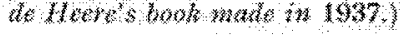

FIG. 3. H. F. McClintock: Old Ireland Eo Highland Dress (Dundalgan Press, 1950).

described as the Irish dress was rapidly disappearing. Already by 1691 the clothes worn and produced in Ireland could be easily classified by English standards: 'The Cloathing [of the Irish] is a narrow sort of Frieze, of about twenty Inches broad, whereof two foot, call'd a Bandle, is worth from $3 \frac{1}{2}$ to $18 d$. Of this, Seventeen Bandles make a Man's Suit, and twelve make a cloak' [23]. The interest in Irish dress that William Petty expresses in his Political Anatomy of Ireland shows a shift from the civilisational attitude during Elizabethan rule towards an economic interest in post-Commonwealth England; he no longer writes for the Court but for the City. His observations of Irish apparel are part of an outline to modernise the manufacturing and trading of clothes in Ireland. In this light, the later Irish counter-call to 'dress in Irish materials' can be seen as an answer to the realisation of the importance of the textile industry to the industrial evolution and autonomy of a nation. When the Irish are asked to dress 'in home-made fabrics' [24] in 1886, this is done explicitly to further 'the development of home trade' [25]. The drawings that accompany this call show English dresses made of Irish fabrics.

Consequently, by the nineteenth century the difference, which was perceived by English visitors to Ireland, was one of habit rather than appearance. Joseph Walker, the first scholar who devoted a whole book to the study of Irish clothes, thought the story 

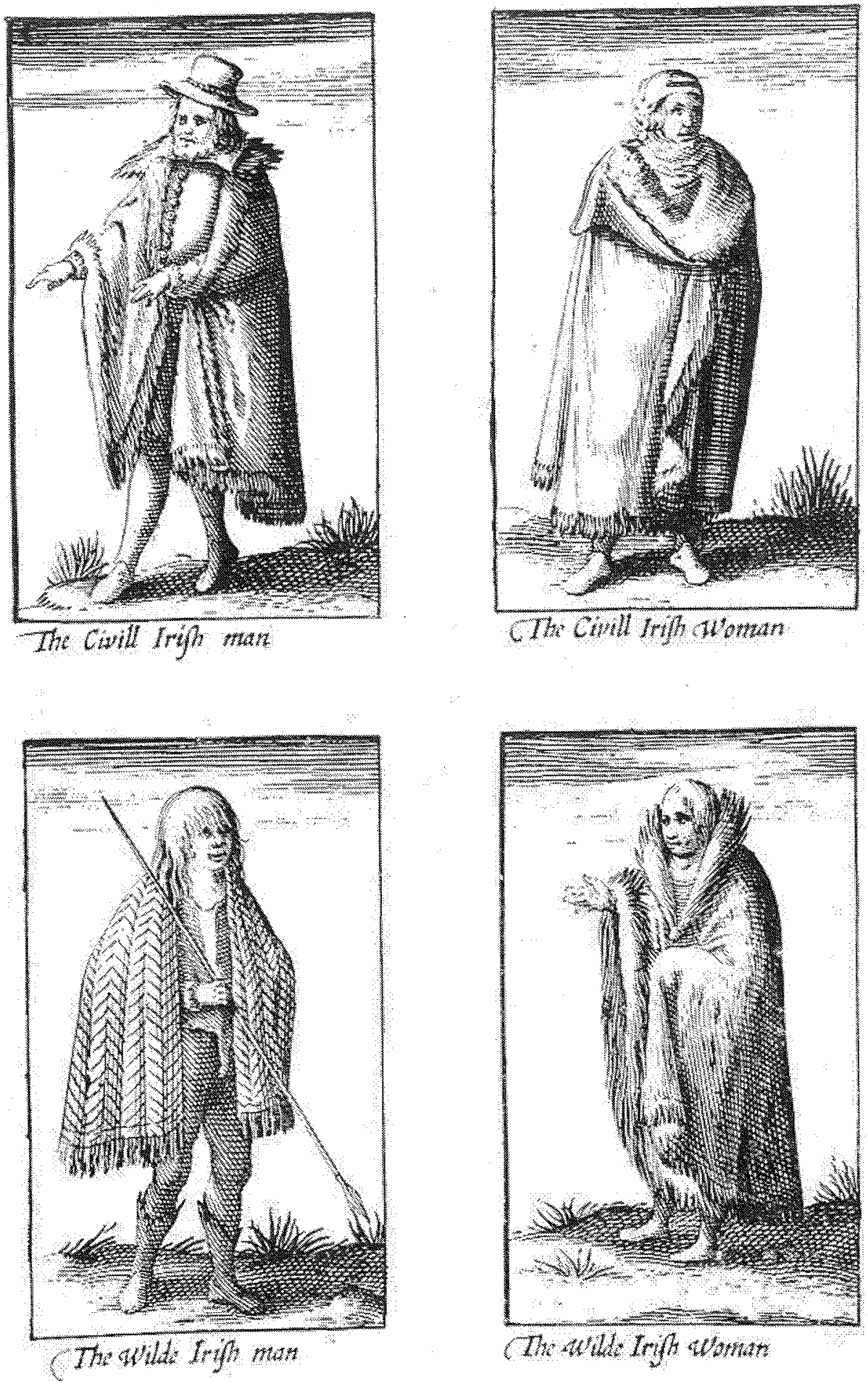

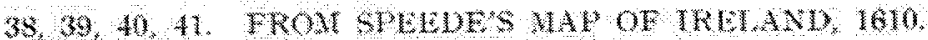

FIG. 4. H. F. McClintock: Old Ireland \& Highland Dress (Dundalgan Press, 1950). 
of Irish dress had come to an end by the time he first published his history in 1788. For him, it started at the beginning of the seventeenth century 'that the Irish dress was to feel the influence of fashion, and to assume a new form' [26]. Later in the seventeenth century 'the Mantle and Trouse began to fall into disuse amongst the Irish peasantry' [27]. After 1700 Irish dress succumbed to the laws of (international) fashion, and Walker is no longer able to discern anything particularly Irish. Some of the Irish may still have a particular language or music [28]. Their clothes, on the other hand, had merely become a cheaper, out-of-fashion version of English dress. When Queen Victoria visited Cork in 1849 she saw people who looked different from those of her usual surroundings, but which might as well have been from Northumberland or anywhere else unfashionable in the UK: '[The women] wear no bonnets, and generally long blue cloaks; the men are very poorly, often raggedly dressed; and many wear blue coats and short breeches with blue stockings' [29]. In contrast to the blue of Cork, Harriet Martineau describes 'the district of the red petticoats-the red flannel and frieze, which form a part of the dress of most of the Galway people' [30]. The old difference of cultural development had been turned into one of economical evolution and the resulting social classes, and the Irish were no longer uncivilised but unfashionable.

With the apparel becoming more and more English during the nineteenth century, the essence of Irishness turned inward. Matthew Arnold is a famous propagator of such a new Irishness: 'It is not in the outward world and visible world of material life that the Celtic genius of [...] Ireland can at this day hope to count for much; it is in the inward world [...]. It cannot count appreciably now as a material power; but [...] as a spiritual power' [31]. This spiritual power was soon to be connected to another inward feature: the Irish race. As Robert Young was able to show, it was only a short step from the praise of the plurality of cultures before 1800 to the concept of race as it was developed in the nineteenth century [32]. This notion of different races was employed enthusiastically to explain the fact that more than 200 years after John Davies's Discovery of the True Causes why Ireland was never Entirely Subdued complete rule over Ireland was still not achieved, even though Irish customs and manners had been abandoned by most. The fundamental cause for the political problems in Ireland, that is, the ongoing violent resistance against British rule, was no longer to be found in the outward appearance, which could be easily altered, but in the inner essence: 'the source of all evil lies in the race, the Celtic race of Ireland'. And because this race is not seen to be capable of being civilised, that is, becoming British, the aim (of some) is no longer to change the Irish, but to get rid of them: 'The race must be forced from the soil; by fair means, if possible; still they must leave' [33]. The particularity of people's exterior is no longer an accidental characteristic of an otherwise universally equal human being, but mankind itself is subdivided into different species. The essence of each species is believed to be unalterable: 'Neither time nor climate seems to have any effect on a race' [34]. In turn, this means that race determines the outlook of all cultural artefacts: 'Race is everything: literature, science, art-in a word, civilisation, depends on it' [35]. One's culture and therefore one's dress is now the natural outward sign of one's inner nature. But what if the Irish are Irish inside, but do not show any outward signs of this Irishness, that is, do not wear an Irish dress?

Douglas Hyde tried to answer this conundrum. He is looking for a visible, outward Irishness, but he also adheres to the nineteenth-century beliefs on racial and innate qualities. He is, as I will try to show, torn between the acknowledgement of an inner Irishness and the need to explain a missing outward Irishness which, in turn, furthers 
the need to proclaim an inward Irishness. Close to the end of his Necessity for De-Anglicising Ireland', Hyde comes to the question of the right garb for the Irish. I will quote his comment at length, not least because this interesting passage has not found its way into the authoritative Field Day Anthology:

[Our youth has] been introduced to the use of a thoroughly good and Irish garb. Wherever the warm striped green jersey of the Gaelic Athletic Association was seen, the Irish manhood and Irish memories were rapidly reviving. The torn collars and ugly neckties hanging awry and far better not there at all, and dirty shirts of bad linen were banished, and our young hurlers were clad like men and Irishmen, and not in the shoddy second-hand suits of Manchester and London shop-boys. Could not this alteration be carried still further? Could we not make that jersey still more popular, and could we not, in places where both garbs are worn, use our influence against English second-hand trousers, generally dirty in front, and hanging in mutty tatters at the heels, and in favour of the cleaner worsted stockings and neat breeches which many of the older generation still wear? Why have we discarded our own comfortable frieze? Why does every man in Connemara wear home-made and home-spun tweed, while in the midland counties we have become too proud for it, though we are not too proud to buy at every fair and market the most incongruous cast-off clothes imported from English cities, and to wear them? Let us, as far as we have any influence, set our face against this aping of English dress, and encourage our women to spin and our men to wear comfortable frieze suits of their own wool, free from shoddy and humbug. [36]

According to the Oxford English Dictionary, 'humbug' is not only another word for nonsense; a humbug is also a deceitful person who pretends to be something he or she is not. By the 'aping of English dress' the Irish are pretending to be what they, in Hyde's eyes, can never be: English. This image of wearing an unfitting dress can be found in many political texts of this time. $₫$ writes, for example: 'God gives no second gift to a nation if it flings aside its birthright. We cannot put on the ideals of another people as a garment' [37]. Even more explicit is Michael Collins: 'English civilization [is] fashioned out of their history. For us it is a misfit. It is a garment, not something within us' [38]. But whereas $ઋ$ and Collins seem to condemn all garments as unnatural, because they are not something within, not innate, Hyde seems to acknowledge the need for a visible Irishness. $ઋ$ and Collins believe Irishness to be inside, but they make no attempt to explain the consequences of such innate Irishness, if it does not show on the outside. Hyde seems to sense this dilemma and is promoting a dress that is more genuine, more authentic, more natural, surely more manly and, most of all, more Irish than other dresses. But if the Irish dress is the natural dress for the Irish people, why do they not wear it at present?

Hyde portrays the break with a more natural past as an active process: 'What the battleaxe of the Dane, the sword of the Norman, the wile of the Saxon were unable to perform, we have accomplished ourselves' [39]. Obviously, the Irish are able to choose deliberately what they want to wear, even though they have chosen the wrong garment, one that does not fit. Hyde admits further that there is no turning back to this first nature from which the Irish have turned away: 'We have at last broken the continuity of Irish life, [...] the Celtic race [...] finds itself deprived and stript of its Celtic characteristics, cut off from the past' [40]. The Irish are stripped, naked, but even though their Irishness is supposed to be inside, this naked state is not desirable. To 
reach a new natural state, Hyde sets up what seems to be a paradoxical task: 'we must strive to cultivate everything that is most racial, most smacking of the soil, most Gaelic, most Irish' [41]. That which is supposed to be given, race and soil, has to be artificially produced, that is to say, the Irish identity has to be cultivated; what is given has also got to be chosen. The Irish dress, a sign of civilisation and of a free will that differentiates man from beast, has to become the index of a natural, given culture. The Irish are supposed to choose their naturally determined apparel.

Hyde seems to be a servant to two masters here: the Romantic doctrine of particularity on the one hand, and the Enlightenment policy of universally acknowledgeable representation on the other. When Hyde stresses the particularity of the Irish he is forced to do that under the rules of representation; that is, he has to prove the right to form an individual nation by obliging to universal rules. As it is discernible in Hyde's text, his presentation of an Irish nature is an attempt to disregard the identification by others as superficial and show that the real Irish identity lies 'at the bottom of the Irish heart, and prevents us from becoming citizens of the Empire' [42]; but to show the Irish heart he has to dress the Irish in an Irish dress. Hyde seems to be stuck in a double bind of an enabling acknowledgement that identities are constructed and the need to rescue one's identity from arbitrariness. He seems to sense that an inside is supplementary to the outside, but shuns the consequences.

Two roads have been taken out of this dilemma: Daniel Corkery and other promulgators of a Hidden Ireland deny the existence of such a rift between inside and outside Irishness. For them, the real Irish still show their Irishness. As a consequence, everyone not wearing an Irish dress (and not singing an Irish song, not dancing an Irish dance, etc.) cannot be Irish. Such reasoning is difficult to refute, because it is based on circularity: everyone who dresses (speaks, sings, dances, etc.) Irish is Irish, and everyone who is Irish dresses (speaks, sings, dances, etc.) Irish. It only becomes problematic when individuals who are not dressing Irish are to be persuaded to dress, and thereby become, Irish. A lot of scientific research on the cultural history of Ireland was pursued during the 1930s and 1940s, and Henry Foster McClintock brought together the relevant facts on Irish dress. However, a book like McClintock's Handbook on the Traditional Irish Dress: with Suggestions for Designing an Irish Uniform or National Dress for Irish Men on Historic Lines obviously transgresses the boundaries of objectively observing science and tries to form a common outlook to forge a common, uniform inside. As is well known, such propagation of an Irish Ireland had significant political consequences for a modern, heterogeneous nation. The dangers of such politics cannot be discussed here, but have been criticised by many.

On the other hand, Hyde's dilemma was countered by an affirmation of the constructiveness of Irishness. One of the first, who affirmed the idea of a constructed identity, was W. B. Yeats. He seemed to be less concerned about the naturalness of his clothing. Already in the 1893 preface to The Celtic Twilight he takes a much more pragmatic approach:

The things that man has heard and seen are threads of life, and if he pull them carefully from the confused distaff of memory, any who will can weave them into whatever garments of belief please them best. I too have woven my garment like another, but shall try to keep warm in it, and shall well be content if it do not unbecome me. [43]

Yeats does not seem to have a problem with the artificiality of his clothing; he acknowledges the cultural labour involved in the creation of his dress. He seems to 
know that it does not matter whether the Irish are wearing 'motley' or 'green'; they have to wear a dress to be anyone at all. In giving primacy to the outside of things, he is in agreement with another late Romantic who has lost faith in a true core behind the false world of appearances: Friedrich Nietzsche. This acknowledged forbear of Yeats takes up the traditional metaphor of unveiling or undressing the truth and deconstructs it in his inimitable manner. In his Gay Science he affirms: 'We no longer believe that truth remains truth when the veils are withdrawn; we have lived too much to believe this. Today we consider it a matter of decency not to wish to see everything naked' [44]. For Nietzsche, as for Yeats, truth does not remain truth once it is unveiled, a natural core cannot be found. An identity for Yeats as well as for Nietzsche is always a social identity, a mask that hides the bundle of contingencies everyone's life is. For a nation this means that it can only have an identity on the outside; that identity can always only be superficial.

Following this preference for a constructed, outward identity is Declan Kiberd, the most recent example for thinking, albeit metaphorically, about identity in terms of clothing. I cite his famous account that closes his Inventing Ireland (1995):

If the notion of 'Ireland' seemed to some to have become problematic, that was only because the seamless garment once wrapped like a green flag around Cathleen ní Houlihan had given way to a quilt of many patches and colours, all beautiful, all distinct, yet all connected too. [45]

No longer does he proclaim a core Irishness (Cathleen ní Houlihan), which is dressed in an Irish (green) dress, but he suggests, or rather recommends, a fabric which seems to be all surface, not wrapping any given core. Rightly, this concept has also been criticised: If it's only up to the 'quilt', are there any limits to being Irish? Can anyone be Irish? And if there are no limits, does that leave any significance to the term 'Irish'? If there's no inside, is there any sense in the word 'outside'?

What can be said as a first result is that clothes have always played an important, although very diverse, part in the discourses on Ireland and Irishness, by external and internal observers alike. However, the idea that a particular Irish dress might be the expression of the particularity of Irishness is only a recent one, strongly linked to the idea of a particular Irish race and its determining power. This expression of Irishness might be read as a reaction against the legal and economic discourses that governed the thinking about Irish dress before the Irish Renaissance. Since this resurgence of active proclamation and production of an Irish identity, the circular dependence of a given, inner core and a chosen, outward appearance seems indestructible. Rather than either proclaiming a core identity (regardless of any superficial apparel) or declaring any essence as non-existing (and thereby affirming a postmodern superficiality), I would suggest acknowledging the reciprocity of such notions if we want to understand the difficult idea of an Irish dress. And I think it would be worth trying, because even today the choice between an H\&M and Aran sweater is discussed in terms of losing or re-gaining one's identity by many, proving adherence to the Renaissance insight that 'there is not a little in the garment to the fashioning of the mind'.

\section{NOTES}

[1] Irish Clothing Committee, An Appeal for Clothing the Naked and Destitute Irish (1847).

[2] Anonymous, The Viceregal Garden Party: How to Dress in Irish Materials (Freeman Pamphlets, 1886). 
[3] Giraldus Cambrensis, Topographica Hibernice, translated by John J. O'Meara (Dolmen Press, 1982), p. 101. Cambrensis's study dates from the beginning of the fourteenth century.

[4] Edmund Spenser, A View of the Present State of Ireland, ed. W. L. Renwick (Clarendon Press, 1970 ), p. 48. The text was probably composed around 1596 but not published before 1633 .

[5] Spenser, $A$ View, p. 50. The 'mantle' and the 'long glib' are stereotypical features of the Irish apparel in most Renaissance/Elizabethan descriptions of Ireland; see, for example, Barnaby Rich's A New Description of Ireland (1610). Compare Luke Gernon's more detailed and benevolent depiction in his A Discourse of Ireland (c.1620); reprinted in C. Litton Falkiner, Illustrations of Irish History and Topography (Longman, Green, 1904), pp. 348-362.

[6] Spenser, $A$ View, p. 51.

[7] Spenser, $A$ View, pp. 51-52.

[8] Spenser, $A$ View, p. 52.

[9] Spenser, $A$ View, p. 69.

[10] Joseph C. Walker, A Historical Essay on the Dress of the Ancient and Modern Irish (Christie, 1818 [1788]), p. 78.

[11] John Davies, Discovery of the True Causes why Ireland was never Entirely Subdued (Irish University Press, 1969 [1612]), p. 2.

[12] Davies, Discovery, p. 259.

[13] Davies, Discovery, p. 272.

[14] Davies, Discovery, p. 271.

[15] Spencer, $A$ View, p. 51.

[16] Spenser, $A$ View, p. 52.

[17] Spenser, $A$ View, p. 70.

[18] See Laura Levine, Men in Women's Clothing: Anti-theatricality and Effeminization, 1579-1642 (Cambridge University Press, 1994).

[19] See Marvin Harris, The Rise of Anthropological Theory: A History of Theories of Culture (Routledge \& Kegan Paul, 1969).

[20] The ethnologist Gregory Bateson calls this process schismogenesis; see 'Culture Contact and Schismogenesis' (1935), in Steps to an Ecology of Mind (Ballentine, 1972), pp. 61-72.

[21] See Raymond Williams, Keyzuords: $A$ Vocabulary of Culture and Society (Fontana, 1976), pp. 76-82.

[22] See Johann Gottfried Herder, Outlines of a Philosophy of the History of Man (Hansard, 1800), p. 249.

[23] William Petty, The Political Anatomy of Ireland, ed. John O'Donovan (Irish University Press, 1970 [1691]), p. 98 .

[24] Anonymous, The Viceregal Garden Party, p. 3.

[25] Anonymous, The Viceregal Garden Party, p. 10.

[26] Walker, $A$ Historical Essay, p. 86. The next scholar, who worked extensively on Irish clothes, also situates 'the decline and fall of the old national dress' in the seventeenth century; see H. F. McClintock, Handbook on the Traditional Old Irish Dress: with Suggestions for Designing an Irish Uniform or National Dress for Irish Men on Historic Lines (Dundalgan, 1958), p. 17. Ample illustrations of the development of the Irish dress can be found in Mairead Dunlevy, Dress in Ireland (Batsford, 1989).

[27] Walker, $A$ Historical Essay, p. 84.

[28] Compare Arthur Young, Arthur Young's Tour in Ireland in the Years 1776, 1777 and 1778, ed. A. W. Hutton, 2 vols (George Bell, 1892).

[29] Victoria Travels: Goumeys of Queen Victoria between 1830 and 1900, with Extracts from Her foumal, ed. David Duff (Frederick Muller, 1970), p. 122.

[30] Harriet Martineau, Letters from Ireland (Chapman, 1852), p. 77.

[31] Matthew Arnold, 'On the Study of Celtic Literature' (1867), in On the Study of Celtic Literature and Other Essays, ed. Ernest Rhys (J. M. Dent, 1910), p. 22.

[32] See Robert J. C. Young, Colonial Desire: Hybridty in Theory, Culture and Race (Routledge, 1995), p. 40.

[33] Robert Knox, The Races of Men: A Fragment (Renshaw, 1850), p. 379.

[34] Knox, The Races of Men, p. 181.

[35] Knox, The Races of Men, p. v.

[36] Douglas Hyde, 'The Necessity for De-Anglicising Ireland', in The Revival of Irish Literature, ed. Charles Gavan Duffy, George Sigerson and Douglas Hyde (Fisher Unwin, 1894), p. 158.

[37] $₫$, 'Nationality and Imperialism', in Ideals in Ireland, ed. Lady Gregory (Unicorn, 1901), p. 20. 
[38] Michael Collins, 'Distinctive Culture', in The Path to Freedom (Mercier Press, 1968), p. 98.

[39] Hyde, 'De-Anglicising Ireland', p. 128.

[40] Hyde, 'De-Anglicising Ireland', p. 128.

[41] Hyde, 'De-Anglicising Ireland', p. 159.

[42] Hyde, 'De-Anglicising Ireland', p. 121.

[43] William Butler Yeats, The Celtic Twilight: Men and Women, Dhouls and Faeries (Lawrence and Bullen, 1893), pp. ix-x.

[44] Friedrich Nietzsche, The Gay Science, translated by Walter Kaufmann (Vintage, 1974), p. 38.

[45] Declan Kiberd, Inventing Ireland: The Literature of the Modern Nation (Vintage, 1996), p. 653. 